\title{
Pemilihan Kepala Desa Serentak 2019 di Indonesia: Implementasi dan Tantangan
}

\author{
Sardjana Orba Manullang ${ }^{1}$, Megasuciati Wardani ${ }^{2}$, Sitti Nur Alam ${ }^{3}$, Sri Sudono Saliro \\ ${ }^{1}$ Universitas Krisnadwipayana \\ ${ }^{2}$ Sekolah Tinggi Ilmu Sosial dan Politik \\ ${ }^{3}$ Universitas Yapis Papua \\ ${ }^{4}$ IAI Sultan Muhammad Syafiuddin Sambas \\ Correspondence email: somanullang@unkris.ac.id; megasuciatiwardani@gmail.com; azkadzar@gmail.com; \\ srisudonosalirofh@gmail.com
}

\begin{abstract}
Abstrak. Penelitian ini bertujuan untuk menganalisa bagaimana implementasi pemilihan kepala desa serentak 2019 di Indonesia, dan bagaimana tantangan pelaksanaan pemilihan kepala desa serentak tahun 2019 di Indonesia. Penelitian ini menggunakan metode penelitian kepustakaan dengan pendekatan deskriftif analisis. Hasil kesimpulan tulisan ini adalah pelaksanaan pemilihan kepala desa serentak tahun 2019 di Indonesia masih terdapat perbedaan-perbedaan syarat administrasi, yang disebabkan oleh perbedaan-perbedaan aturan hukum pada tingkat daerah kabupaten, baik itu regulasi pemilihan kepala desa pada peraturan daerah kabupaten maupun pada tataran teknis peraturan bupati tentang teknis pelaksanaan pemilihan kepala daerah. Selain itu, yang menjadi tantangan pada pelaksanaan pemilihan kepala desa adalah pada pendataan pemilih, regulasi penyelesaian sengketa perselisihan pemilihan kepala desa, dan politik uang.
\end{abstract}

Kata Kunci: Pemilihan, Kepala Desa, Tantangan

\begin{abstract}
This study aims to analyze how the implementation of the 2019 simultaneous village head elections in Indonesia, and how the challenges of implementing the 2019 simultaneous village head elections in Indonesia. This research uses literature research method with deriftive approach of analysis. The conclusion of this paper is the implementation of simultaneous village head elections in 2019 in Indonesia there are still differences in administrative requirements, caused by differences in the rule of law at the district level, be it the regulation of the selection of village heads in district regulations and at the technical level of regent regulations on the technical implementation of regional head elections. In addition, the challenges in the implementation of village head elections are on voter data collection, regulation of dispute resolution of village head elections, and money politics.
\end{abstract}

Keywords: Elections, Village Heads, Challenges

\section{PENDAHULUAN}

Undang-Undang Dasar Negara Republik Indonesia Tahun 1945 yang selanjutnya disingkat UUD 1945 di dalam Pasal 1 Ayat (2) mengatakan bahwa kedaulatan ada di tangan rakyat dan dilaksanakan menurut undang-undang dasar. ${ }^{1}$ Pelaksanaan kedaulatan di tangan rakyat dilakukan melalui Pemilihan Umum (Pemilu) dengan asas pelaksanaan secara langsung, umum, bebas, rahasia, jujur dan adil setiap 5 (lima) tahun sekali. Pemilu diselenggarakan untuk memilih anggota Dewan Perwakilan Rakyat, Dewan Perwakilan Daerah, Presiden dan Wakil Presiden dan Dewan Perwakilan Rakyat Daerah. ${ }^{2}$ Ketentuan pelaksanaan Pemilu sebagaimana di atas termuat dalam Pasal 22E UUD 1945 yang tentunya berbeda dengan pelaksanaan pemilihan kepala desa.

Landasan pemikiran mengenai desa atau yang disebut dengan nama lain telah ada sebelum Negara Kesatuan Republik Indonesia terbentuk. Sebagai bukti keberadaannya, Penjelasan Pasal 18 Undang-Undang Dasar Negara Republik Indonesia Tahun 1945 (sebelum perubahan) menyebutkan bahwa "Dalam territori Negara Indonesia terdapat lebih kurang 250 "Zelfbesturende landschappen" dan "Volksgemeenschappen", seperti desa di Jawa dan Bali, Nagari di Minangkabau, dusun dan marga di Palembang, dan sebagainya. Daerah-daerah itu mempunyai susunan Asli dan oleh karenanya dapat dianggap sebagai daerah yang bersifat istimewa. Negara Republik Indonesia menghormati kedudukan daerah-daerah istimewa tersebut dan segala peraturan negara yang mengenai daerah-daerah itu akan mengingati hak-hak asal usul daerah tersebut". Oleh sebab itu, keberadaannya wajib tetap diakui dan diberikan jaminan keberlangsungan hidupnya dalam Negara Kesatuan Republik Indonesia. ${ }^{3}$

${ }^{1}$ Sekretariat Jenderal MPR RI 2018, “Undang-Undang Dasar Negara Republik Indonesia Tahun 1945” (2018), Lihat Pasal 1 ayat (2).

2 Sri Sudono Saliro dkk., "Hak Memilih Tuna Aksara Pada Pelaksanaan Pemilu Serentak 2019 Di Kota Singkawang," Jurnal Mahkamah : Kajian Ilmu Hukum Dan Hukum Islam 5, no. 1 (16 Juni 2020): hal. 94, doi:10.25217/jm.v5i1.725.

${ }^{3}$ Kementerian Sekretariat Negara RI, "Undang-Undang Nomor 6 Tahun 2014 Tentang Desa" (2014), Lihat Penjelasan Atas UU No. 6 Tahun 2014 tentang Desa. 
Keberagaman karakteristik dan jenis Desa, atau yang disebut dengan nama lain, tidak menjadi penghalang bagi para pendiri bangsa (founding fathers) ini untuk menjatuhkan pilihannya pada bentuk negara kesatuan. Meskipun disadari bahwa dalam suatu negara kesatuan perlu terdapat homogenitas, tetapi Negara Kesatuan Republik Indonesia tetap memberikan pengakuan dan jaminan terhadap keberadaan kesatuan masyarakat hukum dan kesatuan masyarakat hukum adat beserta hak tradisionalnya. Tentunya dalam hal ini, Negara mengakui jika sesuai dengan perkembangan masyarakat dan prinsip Negara Kesatuan Republik Indonesia yang diatur dalam undang-undang.

Undang-Undang Nomor 6 Tahun 2014 Tentang Desa yang diundangkan di Jakarta pada tanggal 15 Januari 2014 ini merupakan penjabaran lebih lanjut dari ketentuan sebagaimana dimaksud dalam Pasal 18 Ayat (7) dan Pasal 18B Ayat (2) UUD 1945 yaitu: ${ }^{4}$

a) Memberikan pengakuan dan penghormatan atas desa yang sudah ada dengan keberagamannya sebelum dan sesudah terbentuknya NKRI;

b) Memberikan kejelasan status dan kepastian hukum atas desa dalam sistem ketatanegaraan RI demi mewujudkan keadilan bagi seluruh rakyat Indonesia;

c) Melestarikan dan memajukan adat, tradisi dan budaya masyarakat desa;

d) Mendorong prakarsa, gerakan, dan partisipasi masyarakat desa untuk pengembangan potensi dan aset desa guna kesejahteraan bersama;

e) Membentuk pemerintahan desa yang professional, efisien, dan efektif, terbuka serta bertanggung jawab;

f) Meningkatkan pelayanan publik bagi warga masyarakat desa guna mempercepat perwujudan kesejahteraan umum;

g) Meningkatkan ketahanan sosial budaya masyarakat desa guna mewujudkan masyarakat desa yang mampu memelihara kesatuan sosial sebagai bagian dari ketahanan nasional;

h) Memajukan perekonomian masyarakat desa serta mengatasi kesenjangan pembangunan nasional; dan

i) Mempercepat masyarakat desa sebagai subjek pembangunan.

UU No. 6 tahun 2014 tentang Desa dalam rangka mengoptimalkan penyelenggaraan pemerintahan desa, pelaksanaan pembangunan Desa, pembinaan kemasyarakatan Desa, dan pemberdayaan masyarakat Desa. Dengan demikian, lingkup pengaturan Peraturan Pemerintah Nomor 43 Tahun 2014 ialah penataan Desa, kewenangan Desa, Pemerintahan Desa, tata cara penyusunan peraturan di Desa, keuangan dan kekayaan Desa, pembangunan Desa dan pembangunan kawasan perdesaan, badan usaha milik Desa, kerja sama Desa, lembaga kemasyarakatan Desa dan lembaga adat Desa, serta pembinaan dan pengawasan Desa oleh camat atau sebutan lain. Berkaitan dengan pemilihan kepala desa sebagaimana termuat dalam Pasal 46 Peraturan Pemerintah No. 24 Tahun 2014 tentang Peraturan Pelaksanaan Undang-Undang Nomor 6 Tahun 2014 tentang Desa bahwa ketentuan lebih lanjut mengenai pemilihan kepala desa diatur dengan Peraturan Menteri. ${ }^{5}$

Selanjutnya Peraturan Menteri Dalam Negeri Republik Indonesia Nomor 112 Tahun 2014 Tentang Pemilihan Kepala Desa sebagai landasan hukum dari pelaksanaan pemilihan kepala desa. Dalam Pasal 1 angka 5 bahwa pemilihan kepala desa adalah pelaksanaan kedaulatan rakyat di desa dalam rangka memilih kepala desa yang bersifat langsung, umum, bebas, rahasia, jujur dan adil. Pemilihan kepala desa dilakukan secara serentak satu kali atau dapat bergelombang. Mengenai ketentuan pelaksanaan pemilihan kepala desa secara serentak diatur dengan Peraturan daerah Kabupaten/Kota. ${ }^{6}$

Pelaksanaan Pemilihan Kepala Desa di Indonesia pada tahun 2019 dalam rangka melaksanakan ketentuan Pasal 49 ayat (1) mengacu kepada Peraturan Menteri Dalam Negeri Republik Indonesia Nomor 112 Tahun 2014 Tentang Pemilihan Kepala Desa, maka setiap daerah Kabupaten membuat Peraturan Daerah. Pembentukan peraturan daerah berdasarkan pertimbangan efektivitas, efisiensi, dan rasional sesuai dengan kebutuhan dan kemampuan daerah serta adanya koordinasi, integrasi, sinkronisasi dan simplifikasi serta komunikasi kelembagaan antara pusat daerah sehingga terlaksana suatu pemilihan kepala desa yang benar-benar mencerminkan kehendak masyarakat desa dalam menentukan pemimpin terbaiknya. ${ }^{7}$

Sesuai dengan penjelasan diatas tulisan ini ditulis untuk membahas: pertama, bagaimana implementasi pemilihan kepala desa serentak di Indonesia pada tahun 2019. Dan kedua, apa saja tantangan yang dihadapi pada

${ }^{4}$ Sekretariat Jenderal MPR RI 2018, Undang-Undang Dasar Negara Republik Indonesia Tahun 1945, Berbunyi : Susunan dan tata cara penyelenggaraan pemerintahan daerah diatur dalam undang-undang.

${ }^{5}$ Kementerian Sekretariat Negara RI, "Peraturan Pemerintah Republik Indonesia Nomor 43 Tahun 2014 tentang Peraturan Pelaksanaan Undang-Undang Nomor 6 Tahun 2014 tentang Desa” (2014), Pasal 46.

${ }^{6}$ Kementerian Sekretariat Negara RI, "Peraturan Menteri Dalam Negeri Republik Indonesia Nomor 112 Tahun 2014 Tentang Pemilihan Kepala Desa” (2014), Pasal 49 Ayat (1).

${ }^{7}$ Haris Mubarak dan Indra Fauzan, "Sistem Pemilihan Kepala Desa dan Pengangkatan Lurah serta Pengaruhnya Terhadap Pelayanan Publik: Studi Kasus Perbandingan di Kota Jambi dan Muaro Jambi,” Politeia: Jurnal Ilmu Politik 11, no. 2 (2019): hal. 3. 
pelaksanaan pemilihan kepala desa serentak tahun 2019. Tulisan mengenai pemilihan kepala desa telah banyak di tulis, seperti Pertama, skripsi Habibi dengan judul "Tinjauan Siyasah Syar'iyah dan Perda Kabupaten Sampang No. 5 Tahun 2006 terhadap Pelaksanaan Pemilihan Kepala Desa Di Desa Daleman Kecamatan Kedungdung Kabupaten Sampang" tahun 2012. Skripsi ini membahas pelaksanaan pemilihan kepala desa dari sudut pandang siyasah syar'iyah dan perda no. 5 tahun 2006. Pada ketentuan perda tersebut, masih mengacu kepada UU 32 tahun 2004 tentang pemerintahan daerah, sebab UU No. 6 tahun 2014 tentang desa masih belum ada. Hasil penelitian ditemukan bahwa proses dan mekanisme pemilihan kepala desa daleman mulai dari pembentukan panitia pemilihan kapala desa, penjaringan bakal calon sampai pada panitia pemilihan sudah sesuai dengan prosedur siyasah syar'iyah. ${ }^{8}$

Kedua, skripsi yang ditulis oleh Susi Faizah, dengan judul "Pelaksanaan Pemilihan Kepala Desa Di Kecamatan Sukodono Kabupaten Sidoarjo Ditinjau Dari Hukum Islam" tahun 1995. Skripsi ini membahas tentang pandangan hukum terhadap pelaksanaan pemilihan kepala desa yang diwarnai dengan membagi-bagikan uang oleh calon kepala desa kepada masyarakat setempat untuk memperoleh suara tertinggi. ${ }^{9}$

Ketiga, skripsi yang ditulis oleh Muhammad Yunus, dengan judul "Pemilihan Kepala Desa Serentak Tahun 2015 (Studi Kasus di Kecamatan Keera Kabupaten Wajo)" tahun 2016. Hasil penelitian ini menunjukkan bahwa pilkades merupakan sarana sirkulasi elit dan transfer kekuasaan ditingkat lokal. Dalam konteks ini Pilkades diharapkan secara langsung membuat masyarakat mengerti posisi mereka sebagai proses interaksi antara rakyat dan pemerintah sebagai wujud adanya demokrasi dari rakyat, oleh rakyat, dan untuk rakyat. Beradasarkan dari pengamatan yang dilakukan masih banyak ditemukan pelanggaran-pelanggaran yang merusak nilai-nilai demokrasi itu sendiri mulai dari tahapan persiapan sampai dengan pemungutan suara yang masih beredarnya fenomena uang, pemalsuan berkas calon kandidat, pemalsuan daftar panggilan pemilih, tidak tegasnya Panitia Pengawas dan melanggar Perda Wajo Nomor 5 Tahun 2007 tentang mekanisme Pemilihan Kepala Desa. ${ }^{10}$ Dari penelitian terdahulu diatas, hal yang membedakan dalam tulisan ini yaitu mencoba mendeskripsikan tantangan-tantangan pemilihan kepala desa yang ditemukan, guna perbaikan pelaksanaan pemilihan kepala desa yang lebih demokratis.

\section{METODE}

Metode penelitian pada dasarnya merupakan cara ilmiah untuk mendapatkan data dengan tujuan dan kegunaan tertentu. Berdasarkan permasalahan yang diangkat, jenis penelitian ini menggunakan metode penelitian yang digunakan yaitu metode hukum normatif atau penelitian hukum kepustakaan. Metode ini diartikan sebagai sebuah metode penelitian atas aturan-aturan perundangan baik ditinjau dari sudut hierarki peraturan perundang-undangan (vertikal) maupun hubungan harmoni perundang-undangan (horizontal). ${ }^{11}$ Metode penelitian hukum normatif menggunakan metode pendekatan yuridis normatif. Pendekatan yuridis normatif adalah "suatu pendekatan yang mengacu pada hukum dan peraturan perundang-undangan yang berlaku. ${ }^{12}$

Sumber data yang digunakan dalam penelitian normatif adalah sumber data sekunder, yaitu menggunakan bahan-bahan kepustakaan berupa buku, peraturan perundang-undangan, jurnal, dan karya ilmiah lainnya yang berkaitan dengan masalah yang diteliti. Adapun peraturan perundang-undangan yang digunakan sebagai sumber data adalah:

1). Kementerian Sekretariat Negara RI. Undang-Undang Nomor 6 Tahun 2014 Tentang Desa (2014)

2). Peraturan Pemerintah Republik Indonesia Nomor 43 Tahun 2014 tentang Peraturan Pelaksanaan Undang-Undang Nomor 6 Tahun 2014 tentang Desa (2014).

3). Peraturan Menteri Dalam Negeri Republik Indonesia Nomor 112 Tahun 2014 Tentang Pemilihan Kepala Desa (2014).

Data dalam penelitian ini dianalisis secara deskriptif yaitu data sekunder yang berupa teori, definisi dan substansinya dari berbagai literatur, dan peraturan perundang-undangan sehingga dihasilkan suatu kesimpulan yang dapat dipergunakan untuk menjawab rumusan masalah. ${ }^{13}$

${ }^{8}$ Habibi, “Tinjauan Siyasah Syar'iyah dan Perda Kabupaten Sampang No. 5 Tahun 2006 terhadap Pelaksanaan Pemilihan Kepala Desa Di Desa Daleman Kecamatan Kedungdung Kabupaten Sampang” (Skripsi, Fakultas Syariah UIN Sunan Ampel Surabaya, 2012).

${ }^{9}$ Susi Faizah, "Pelaksanaan Pemilihan Kepala Desa Di Kecamatan Sukodono Kabupaten Sidoarjo Ditinjau Dari Hukum Islam" (Skripsi, UIN Sunan Ampel Surabaya, 1995).

${ }^{10}$ Muhammad Yunus, "Pemilihan Kepala Desa Serentak Tahun 2015 (Studi Kasus di Kecamatan Keera Kabupaten Wajo)" (Skripsi, UIN Alauddin Makassar, 2016).

${ }^{11}$ Peter Mahmud Marzuki, Pengantar Ilmu Hukum (Jakarta: Kencana, 2008), hlm. 23.

${ }^{12}$ Bambang Sunggono, Metode Penelitian Hukum (Jakarta: Raja Grafindo Persada, 2003), hlm. 32.

${ }^{13}$ Soerjono Soekanto, Pengantar Penelitian Hukum (Jakarta: UI Press, 2006), hlm. 250. 


\section{HASIL DAN PEMBAHASAN}

\section{Implementasi Pemilihan Kepala Desa Serentak Di Indonesia Pada Tahun 2019}

Pelaksanaan pemilihan kepala desa serentak di Indonesia tahun 2019, tidak sepenuhnya serentak secara keseluruhan di Indonesia. Makna kata serentak hanya berlaku bagi wilayah kabupaten saja. Misalnya, di Kabupaten Sambas, pelaksanaan pemungutan suara pada pemilihan kepala desa serentak berjumlah 193 desa dilaksanakan pada tanggal 19 Oktober 2019. ${ }^{14}$ Di Kabupaten Bandung sebanyak 199 desa pada tanggal 26 Oktober 2019, Kabupaten Tasikmalaya sebanyak 211 desa pada tanggal 24 Oktober 2019, dan Kabupaten Sukabumi sebanyak 240 desa pada tanggal 17 November 2019. ${ }^{15}$

Khusus mengenai pemilihan Kepala Desa dalam Undang-Undang Nomor 6 Tahun 2014 Tentang Desa diatur agar dilaksanakan secara serentak di seluruh wilayah Kabupaten/Kota dengan maksud untuk menghindari hal negatif dalam pelaksanaannya. Pemilihan Kepala Desa secara serentak mempertimbangkan jumlah Desa dan kemampuan biaya pemilihan yang dibebankan pada Anggaran Pendapatan dan Belanja Daerah Kabupaten/Kota sehingga dimungkinkan pelaksanaannya secara bergelombang sepanjang diatur dalam Peraturan Daerah Kabupaten/Kota Pemilihan kepala Desa dilaksanakan melalui tahapan: persiapan, pencalonan, pemungutan suara dan penetapan, sebagaimana termuat dalam Pasal 41 ayat (1) Peraturan Pemerintah Nomor 43 Tahun 2014 Tentang Peraturan Pelaksanaan Undang-Undang Nomor 6 Tahun 2014 Tentang Desa. ${ }^{16}$ Adapun penjabaran pada setiap tahapan tersebut disajikan dalam bentuk tabel dibawah ini:

Tabel 1. Tahapan dan Kegiatan Pelaksanaan Pemilihan Kepala Desa

\begin{tabular}{|c|c|c|c|}
\hline No & Tahapan & & Kegiatan \\
\hline 1 & 2 & & 3 \\
\hline \multirow[t]{7}{*}{ I. } & Persiapan & 1 & Pembentukan panitia pemilihan Kepala desa Kabupaten \\
\hline & & 2 & Pembentukan Tim Pengawas Pemilihan Kepala desa Kecamatan \\
\hline & & 3 & Pembentukan Tim Penyelesaian Sengketa Pemilihan Kepala desa \\
\hline & & 4 & $\begin{array}{l}\text { Pembentukan Panitia Pilkades dengan Keputusan Badan Permusyawaratan Desa dan } \\
\text { disampaikan secara tertulis oleh Badan Permusyawaratan Desa kepada Bupati melalui Camat }\end{array}$ \\
\hline & & 5 & $\begin{array}{l}\text { Penyusunan dan Pengajuan rencana biaya pemilihan Kepala Desa kepada Bupati melalui } \\
\text { Camat (paling lama } 30 \text { hari setelah terbentuknya panitia pemilihan) }\end{array}$ \\
\hline & & 6 & Persetujuan biaya oleh Bupati (paling lama 30 hari sejak diajukan oleh panitia) \\
\hline & & 7 & Sosialisasi pemilihan Kepala Desa kepada Panitia Pemilihan Kepala Desa \\
\hline \multirow[t]{12}{*}{ II. } & $\begin{array}{l}\text { Pendaftaran } \\
\text { Pemilih Dan } \\
\text { Pencalonan }\end{array}$ & 1 & Pengumuman Daftar Pemilih Sementara (DPS), menerima usul/informasi perbaikan DPS \\
\hline & & 2 & Pengumuman dan Pendaftaran Bakal Calon Kades \\
\hline & & 3 & Pencatatan Daftar Pemilih Tambahan (DP Tambahan) \\
\hline & & 4 & Pengumuman Daftar Pemilih Tambahan (DP Tambahan) \\
\hline & & 5 & Penetapan dan Pengumuman Daftar Pemilih Tetap (DPT) \\
\hline & & 6 & Penelitian kelengkapan administrasi dan klarifikasi \\
\hline & & 7 & $\begin{array}{l}\text { Seleksi Tambahan untuk peserta }>5 \text { orang (persiapan, pelaksanaan dan penetapan) oleh } \\
\text { Panitia Pemilihan kepala desa Kabupaten (Secara Serentak dengan kriteria Pengalaman } \\
\text { bekerja di lembaga pemerintahan, tingkat pendidikan, usia, dan tes akademik) }\end{array}$ \\
\hline & & 8 & $\begin{array}{l}\text { Perpanjangan Pendaftaran jika calon kurang dari } 2 \text { orang (Diperpanjang paling lama } 20 \text { hari, } \\
\text { kalau masih tetap kurang dari } 2 \text { orang, Bupati menetapkan Pilkades melalui Musdes dengan } \\
\text { jangka waktu paling lama } 7 \text { hari) }\end{array}$ \\
\hline & & 9 & $\begin{array}{l}\text { Tes kompetensi wajib untuk bakal calon kades oleh Panitia Pemilihan Kabupaten (Persiapan, } \\
\text { pelaksanaan dan penetapan hasil) }\end{array}$ \\
\hline & & 10 & $\begin{array}{l}\text { Penetapan Nomor Urut calon kades (Penentuan giliran undian nomor urut berdasarkan urutan } \\
\text { waktu pendaftaran) }\end{array}$ \\
\hline & & 11 & Pengumuman calon kades (Pengumuman paling lambat 7 hari sejak tanggal ditetapkan) \\
\hline & & 12 & $\begin{array}{l}\text { Proses pencetakan Surat Suara (Ditambah } 2,5 \% \text { dari jumlah DPT, panitia pemilihan } \\
\text { menyerahkan pas foto calon berwarna dengan ukuran } 4 \mathrm{R}(10,16 \times 15,24 \mathrm{~cm}) \text { kepada Panitia } \\
\text { pemilihan Kades Kabupaten, dengan latar biru dan mengenakan pakaian putih) }\end{array}$ \\
\hline
\end{tabular}

${ }^{14}$ Website Resmi, Sambas.go.id

15 Y. Manggala P Putra, “Sebanyak 1.528 Desa di Jabar Laksanakan Pilkades 2019,” m.republika.co.id, 2019, diakses tanggal 12 Agustus 2020.

${ }^{16}$ Kementerian Sekretariat Negara RI, Peraturan Pemerintah Republik Indonesia Nomor 43 Tahun 2014 tentang Peraturan Pelaksanaan Undang-Undang Nomor 6 Tahun 2014 tentang Desa, Lihat Pasal 41 ayat (1). 


\begin{tabular}{|c|c|c|c|}
\hline & & 13 & $\begin{array}{l}\text { Penyusunan Visi dan Misi Calon Kepala Desa (sebanyak } 3 \text { (tiga) rangkap diserahkan kepada } \\
\text { panitia pemilihan, BPD, dan Pemerintah Desa.) }\end{array}$ \\
\hline & & 14 & Kampanye ( 3 hari sebelum dimulainya masa tenang) \\
\hline & & 15 & Pendistribusian Surat Suara (selambat-lambatnya 2 (dua) hari sebelum hari pemilihan) \\
\hline & & 16 & Masa Tenang (3 hari sebelum hari $\mathrm{H})$ \\
\hline III. & $\begin{array}{l}\text { Pemungutan } \\
\text { Suara }\end{array}$ & 1 & $\begin{array}{l}\text { Pemungutan dan Penghitungan Suara (Pemungutan Suara dimulai pukul } 07.00 \text { dan berakhir } \\
\text { pukul } 12.00 \text { waktu setempat, Penghitungan suara dimulai pukul } 13.00 \text { waktu setempat) }\end{array}$ \\
\hline & & 2 & $\begin{array}{l}\text { Tes Akademik oleh Panitia Pemilihan Kabupaten Untuk calon yang menang mendapatkan } \\
\text { suara pemilih sama, maksimal } 3 \text { hari sejak perhitungan suara (Paling lambat } 3 \text { hari sejak Hari } \\
\text { Perhitungan Suara) }\end{array}$ \\
\hline IV. & $\begin{array}{ll}\text { Penetapan } & / \\
\text { Pengesahan }\end{array}$ & 1 & $\begin{array}{l}\text { Penyampaian hasil pemilihan oleh Panitia Pemilihan kepada BPD dan dari BPD kepada } \\
\text { Bupati melalui Camat }\end{array}$ \\
\hline & & 2 & $\begin{array}{l}\text { Penyampaian keberatan oleh yang bersangkutan maksimal } 3 \text { hari sejak penetapan hasil } \\
\text { pemilihan }\end{array}$ \\
\hline & & 3 & Penyelesaian sengketa atas keberatan oleh Tim Penyelesaian Sengketa (paling lama 30 hari) \\
\hline & & 4 & $\begin{array}{l}\text { Keputusan Final Bupati untuk penyelesaian sengketa dengan mempertimbangkan masukan } \\
\text { dari Tim Penyelesaian Sengketa (Memperhatikan masukan dari panitia pemilihan, BPD, Tim } \\
\text { Fasilitasi Pemilihan Kades Kecamatan, dan panitia pemilihan Kades Kabupaten) }\end{array}$ \\
\hline & & 5 & Bupati menetapkan pengesahan dan pengangkatan calon Kades Terpilih \\
\hline & & 6 & $\begin{array}{l}\text { Pelantikan (paling lama } 30 \text { (tiga puluh) hari terhitung sejak tanggal penerbitan Keputusan } \\
\text { Bupati tentang pengesahan dan pengangkatan calon Kades Terpilih, bertempat di Ibukota } \\
\text { Kabupaten) }\end{array}$ \\
\hline
\end{tabular}

Sumber: Peraturan perundang-undangan

\section{Tantangan Yang Dihadapi Pada Pelaksanaan Pemilihan Kepala Desa Serentak Tahun 2019}

Karakteristik calon kepala desa yang dianggap penting yang harus dilaksanakan, seperti bersikap baik, tegas dan siaga dalam segala bentuk kegiatan masyarakat, hal ini untuk mencari simpatik dalam memenangkan persaingan dengan calon-calon lain, maka masing-masing calon akan menggunakan cara-cara tersendiri untuk memperoleh dukungan suara baik dengan menggunakan cara terpuji maupun dengan cara yang meresahkan masyarakat. Dan tidak jarang calon kepala desa yang sudah terpilih menjadi kepala desa menunjukan sikap yang kurang disukai oleh masyarakat. Terlepas dari persoalan persaingan antar pasangan calon dalam menarik simpati masyarakat, sebetulnya hal yang penting lainnya untuk dilihat dan dilakukan pengawasan yaitu pada aspek panitia pelaksana pemilihan kepala desa.

Kejanggalan pada pelaksanaan pemilihan kepala desa, mulai dari adanya campur tangan pemerintah kabupaten yang dibentuk oleh Bupati secara langsung dalam proses pemilihan yaitu dalam tahapan proses seleksi bakal calon kepala desa, bahkan adanya persyaratan pencalonan "dapat membaca alquran". ${ }^{17}$ Tentu hal ini dianggap merusak nilai dan semangat demokrasi. Selain itu, terdapat beberapa persoalan-persoalan yang terjadi dalam pelaksanaan pemilihan kepala desa serentak, antara lain: pertama, pendataan pemilih. Dalam pemilihan kepala desa masih terdapat masyarakat desa yang tidak terdaftar oleh panitia pemilih. Hal ini di dasari oleh tidak adanya administrasi data kependudukan pemilih. ${ }^{18}$

Kedua, tidak adanya regulasi yang jelas tentang siapa yang berwenang untuk menyelesaikan sengketa perselisihan pemilihan kepala desa. Ketiga, praktik politik uang pada pelaksanaan pemilihan kepala desa, hal ini menjadi sesuatu hal yang biasa terjadi namun sangat sulit sekali untuk di hilangkan dari kebiasaan kontestasi politik. ${ }^{19}$ Melihat tantangan praktik politik uang, kebanyakan masyarakat enggan untuk melaporkan dan mempermasalahkan hal ini, karena secara yuridis masyarakat merasa bahwa sanksi sosial yang diterima oleh individu yang melaporkan adanya praktik politik uang menjadi bahan pertimbangan individu/masyarakat untuk melaporkan hal tersebut.

17 Rudiadi dan Ratna Herawati, "Pemilihan Kepala Desa Serentak Dalam Perspektif Otonomi Desa (Studi Kasus Pelaksanaan Pemilihan Kepala Desa Serentak di Kabupaten Rokan Hilir, Provinsi Riau)," Jurnal Law Reform 13, no. 1 (2017): hal. 135.

18 Muhammad Yunus, "Pemilihan Kepala Desa Serentak Tahun 2015 (Studi Kasus di Kecamatan Keera Kabupaten Wajo)," hal. 65.

${ }^{19}$ Fathur Rozy, Pratama Aditya, dan dkk, "Praktik Politik Uang dalam Proses Pemilihan Kepala Desa Sumberingin Kidul Tahun 2019," Jurnal Socius 7, no. 1 (2020): hal. 43. 


\section{SIMPULAN}

Bahwa pelaksanaan Pemilihan Kepala Desa mengacu pada dasar hukum Peraturan Daerah Kabupaten pada masing-masing daerah, tentang Pemilihan Kepala Desa, dan dituangkan dalam Peraturan Bupati sebagai petunjuk teknis pelaksanaan pemilihan kepala desa. Berdasarkan landasan hukum diatas, maka pelaksanaan Pilkades terdapat beberapa tahapan yaitu: tahapan persiapan, tahapan pendaftaran pemilih dan pencalonan, tahapan pemungutan suara, dan tahapan penetapan/pengesahan. Selain itu, tantangan dalam pelaksanaan pemilihan kepala desa yaitu terdapat perbedaan persyaratan administrasi calon kepala desa di masing-masing daerah, sehingga terkesan tidak ada keseragaman dalam konteks persyaratan calon kepala desa. Adanya politik uang, juga selalu ikut mewarnai persoalan pemilihan baik itu kepala desa, kepala daerah bahkan pemilihan presiden, selalu ada pelanggaran politik uang. Pengaturan kewenangan dalam penyelesaian sengketa perselisihan hasil suara pemilihan kepala desa, menjadi persoalan baru, karena tidak adanya badan pengawas atau yang berwenang dalam penyelesaian sengketa perselisihan hasil suara pemilihan kepala desa.

\section{DAFTAR PUSTAKA}

Fathur Rozy, Pratama Aditya, dan dkk. "Praktik Politik Uang dalam Proses Pemilihan Kepala Desa Sumberingin Kidul Tahun 2019." Jurnal Socius 7, no. 1 (2020): 37-44.

Habibi. "Tinjauan Siyasah Syar'iyah dan Perda Kabupaten Sampang No. 5 Tahun 2006 terhadap Pelaksanaan Pemilihan Kepala Desa Di Desa Daleman Kecamatan Kedungdung Kabupaten Sampang." Skripsi, Fakultas Syariah UIN Sunan Ampel Surabaya, 2012.

Kementerian Sekretariat Negara RI. Peraturan Menteri Dalam Negeri Republik Indonesia Nomor 112 Tahun 2014 Tentang Pemilihan Kepala Desa (2014).

- Peraturan Pemerintah Republik Indonesia Nomor 43 Tahun 2014 tentang Peraturan Pelaksanaan Undang-

Undang Nomor 6 Tahun 2014 tentang Desa (2014).

. Undang-Undang Nomor 6 Tahun 2014 Tentang Desa (2014).

Marzuki, Peter Mahmud. Pengantar Ilmu Hukum. Jakarta: Kencana, 2008.

Mubarak, Haris, dan Indra Fauzan. "Sistem Pemilihan Kepala Desa dan Pengangkatan Lurah serta Pengaruhnya Terhadap Pelayanan Publik: Studi Kasus Perbandingan di Kota Jambi dan Muaro Jambi." Politeia: Jurnal Ilmu Politik 11, no. 2 (2019): 1-18.

Muhammad Yunus. "Pemilihan Kepala Desa Serentak Tahun 2015 (Studi Kasus di Kecamatan Keera Kabupaten Wajo).” Skripsi, UIN Alauddin Makassar, 2016.

Putra, Y. Manggala P. "Sebanyak 1.528 Desa di Jabar Laksanakan Pilkades 2019.” m.republika.co.id, 2019.

Rudiadi, dan Ratna Herawati. "Pemilihan Kepala Desa Serentak Dalam Perspektif Otonomi Desa (Studi Kasus Pelaksanaan Pemilihan Kepala Desa Serentak di Kabupaten Rokan Hilir, Provinsi Riau)." Jurnal Law Reform 13, no. 1 (2017): 132-51.

Saliro, Sri Sudono, Jamiat Akadol, Saiful Rachman, dan Agus Setiawan. "Hak Memilih Tuna Aksara Pada Pelaksanaan Pemilu Serentak 2019 Di Kota Singkawang." Jurnal Mahkamah : Kajian Ilmu Hukum Dan Hukum Islam 5, no. 1 (16 Juni 2020): 93-108. doi:10.25217/jm.v5i1.725.

Sekretariat Jenderal MPR RI 2018. Undang-Undang Dasar Negara Republik Indonesia Tahun 1945 (2018).

Soekanto, Soerjono. Pengantar Penelitian Hukum. Jakarta: UI Press, 2006.

Sunggono, Bambang. Metode Penelitian Hukum. Jakarta: Raja Grafindo Persada, 2003.

Susi Faizah. "Pelaksanaan Pemilihan Kepala Desa Di Kecamatan Sukodono Kabupaten Sidoarjo Ditinjau Dari Hukum Islam.” Skripsi, UIN Sunan Ampel Surabaya, 1995. 